\title{
Financial Inclusion and the Growth of Small Medium Enterprises in Uganda: Empirical Evidence from Selected Districts in Lango Sub Region
}

Marus - Eton ( $\nabla$ emarus@kab.ac.ug )

Kabale University Faculty of Arts and Social Sciences https://orcid.org/0000-0002-9057-8484

Fabian - Mwosi

Barham University College, Kabale Uganda

Constant - Okello-Obura

Makerere University College of Computing and Information Sciences

Abanis - Turyehebwa

Kabale University, Kabale Uganda

Gilbert - Uwonda

Gulu University Faculty of Business and Development Studies

Research

Keywords: Financial Inclusion, Financial Services, SMES, Business Failures

Posted Date: December 31st, 2020

DOI: https://doi.org/10.21203/rs.3.rs-49564/v3

License: (c) (i) This work is licensed under a Creative Commons Attribution 4.0 International License.

Read Full License

Version of Record: A version of this preprint was published at Journal of Innovation and Entrepreneurship on July 9th, 2021. See the published version at https://doi.org/10.1186/s13731-021-00168-2. 


\section{Abstract}

The growth and failure of small and medium enterprises has been a topic of discussions world over amongst policy makers and researchers. This study was guided by the following objectives: To examine the contributions of Small Medium Enterprises (SMEs), to determine the challenges affecting Small Medium Enterprises, to examine how financial inclusiveness supports the growth of Small medium enterprises and to establish the relationship between financial inclusion and Small Medium Enterprises. The study used a cross sectional research design. Descriptive design was used and supplemented by inferential statistics. Correlation and regression analysis were adopted. The study revealed that financial inclusion is significant in supporting SMEs growth. The study also revealed that cost of acquiring and servicing financial services are high, there is also difficulty in using some of the financial services, and the way financial providers treat financial users, some lacked some degree of respect and dignity. The study recommends that financial providers should continue sensitizing the public on the available financial services beyond credit services, which are common and known. Digital financial service providers should encourage their clientele to use digitalized financial services which are cheap, secure and risk averse. Cost of capital should also be reduced to encourage borrowing while SMEs should innovatively produce goods that can be competitive at both domestic and international markets.

\section{Introduction}

Financial inclusion $(\mathrm{FI})$ has gained immense recognition in many upcoming economies as well as at the international level as far as policy is concerned (IMF, 2017). Financial inclusion (FI) is the process of access to and usage of diverse, convenient, affordable financial services (Nwanko and Nwanko, 2014). This is viewed as the ability of some individuals to access and use basic financial services like savings, loans and insurance, which is designed in a manner that is reasonably convenient, flexible and reliable. FI has taken a center stage on economic growth and development in an effort to create wealth amongst citizens of developing countries (IMF, 2018). Fl is an important financial literacy program, which creates the communities' ability to improve on the usage of any kind of financial service from formal financial institutions, which affects the citizen's standards of living, and economic fundamentals which are the major indicators to financial inclusion (Terzi, 2015). The 2010 G20 Summit in Seoul endorsed the Financial Inclusion Action Plan (FIAP).

Garikai, (2011) defines SMEs by capital invested, number of workers employed and sales turnover. The number of employees working in that business and assets value also classifies SMEs UIA, (2016). The definition of Small Medium Enterprises (SMEs) differs from country to country. In some countries the criteria for classification is based on capital and in other countries it is based on the number of employees. Financial inclusion is an antecedent to economic growth through wide participation in various economic activities by the citizenry through numerous startups of Small and Medium Enterprises Cole, ., et al, (2016). In the context of Uganda, SMEs are regarded as an engine of economic growth, development and transformation through innovation and wealth creation (NDPII 2015/16-2019/20). The promotion of SMEs has been a key area of government intervention. SMEs dominate much of the 
country's economy, for example $10 \%$ are active in manufacturing sector, $33 \%$ in commerce, $49 \%$ in service and $8 \%$ in other fields UIA, (2016), and all these are contributing to approximately $90 \%$ in employment which is close to (2.5 million people) of the entire private sector employment and $80 \%$ of manufactured products accounting for $20 \%$ of GDP (UBOS, 2016; UIA2016). The development of SMEs in Uganda is one of the policy agenda of the government in order to boost economic growth and development. The key areas of government interventions is the creation of Micro finance support center, Uganda which offers programs that support the growth and expansion of SME through access to cheap and affordable finance. Some researcher argue that SMES globally are seen as an engine of economic growth and development and its success has a direct effect on the economic growth and development in both developing and developed economies as they have the potential to create jobs(Kristiningsih and Trimarjono, 2014; Ojokuku and Sajuyibe, 2014).OECD (2010a) posits that not all SMEs have the ability to be innovative, however small businesses are often the driving force behind the new radical innovations that are very significant in the economic growth and development. SMEs are also able to exploit the opportunities available at their disposal which had been neglected by already established firms.

Eton maruset al.., (2018) note that SMEs should receive full backing legal protection and stimulus from all stake holders so that it can sustain economic growth and development which would lead to job creation, therefore driving investment into the economy as well as generate revenue to government through taxation. SMEs are firmly attached to the local environment which may represent their source of expertise, networks, business opportunities, and access to funding which would be very important to consider factors that supports its existence at a macro level and therefore one needs to know how policies which are developed in a country can work and how the SMEs adopt these policies which shapes there doing business at the territorial and regional level (OECD, 2016e). The failure by SMEs to deliver good products and services in time to the customers at all levels as a result of challenges such as inadequate funding for their businesses therefore results in to a debate on whether they are well prepared in creating a sustainable economic growth and development in a country (Bowen, Morara and Mureithi, 2009). The study conducted by Abaniset al.., (2013) establishes that SMEs performance in Uganda was largely hampered by inadequate funding characterized by high cost of finance. However, Lack of competition amongst formal financial institutions for financial services reduces access to financing for SMEs. Increased competition and market diversification consequently plays a major role in promoting financial inclusion and productivity of SMEs in the country. Love and Martinez Peria ,(2015) establishes a positive impact on FI depends on the coverage of credit bureaus. A strong competition amongst the financial institutions and low information asymmetries would facilitate financial inclusion amongst SMEs. The key characteristics of an economy which promotes favourable conditions for SME investment and financial inclusion are economic diversification, adequate infrastructural development and healthy competition across all sectors.

This research was inspired by the increasing significance of Small and Medium Enterprises in Uganda's economy and the enduring constraints faced by the SMEs in their operations. This is because the contribution of SMEs to Gross Domestic Product (GDP) and overall economic contribution to Uganda's economy has been a subject of discussion by many scholars (Abanis e t al, 2013). However, no much 
studies has been conducted in SMEs growth in Lango sub region and this research will help identify the specific areas to be addressed if the growth of SMEs is to be achieved. Besides, appreciating the influence of financial inclusion is important in wealth distribution and overall growth of the economy (Nwanko and Nwanko, 2014). The helplessness in accessing financial services by many thwarts opportunities and growth of small and medium enterprises Pande et al., (2012). Preceding studies also indicate affirmative relationship between the access to finance and economic growth Butkiewicz et al, (2005). The problems associated with inadequate access to finance do not only cripple SMEs, but leads to eventual decline in economic development IMF , (2017).

The growth, development and survival of SMEs are affected by various factors that may exist in their operations and management of the businesses. SMEs are created and nurtured in various ways and supported by various stakeholders using different laws and regulations which support their creation. The operations of SMEs in sub Saharan Africa, Uganda and in lango sub-region in particular has contributed to economic growth across the country UBOS, (2016) and there are many successful entrepreneurs in the country. The increase in the number of many financial institutions in the region would indicate an increase in the access to finance which would mean more support to the growth of businesses. However, SMEs in the region are still disproportionately affected by inadequate financing. Adcorp, (2014) observes that the mortality rate of SMEs among African countries remains very high with five out of seven new businesses failing in their first year. This is too high which needed an intervention to reverse the trend. SMEs in developing countries are stagnating and if not supported by developing good policies they will not survive for a long time yet their contribution to economic growth would be enormous (Reeg, 2013). Over the years there is a declining pattern in number of growth of SMEs in the region and this can be associated to various factors. SMEs have often cited some impediments to the smooth performance and operation of SMEs which may lead to others performing below optimum levels or collapse. Olowe, Moradeyo and Babalola, (2013) posit that most SMEs are greatly affected by inadequate financing of their businesses and as a result, they die before reaching their growth stage of their life cycle. It has remained regrettable that in spite of the role that SMEs play in the economy and the support extended to the entrepreneurs in the SMEs sector, most of these SMEs collapses within the first three years after their establishment,(Fatoki and Smit, ,2011). The high failure rates of these SMEs in the region have prompted this study to find ways of redirecting the continuous worrying trends in the SME business sector. This study was guided by the following objectives: 1 . To examine the contributions of Small Medium Enterprises 2. To determine the challenges affecting Small Medium Enterprises. 3. To establish the relationship between financial inclusion and Small Medium Enterprises. 4. To examine how financial inclusiveness supports the growth of Small medium enterprises in region.

This study is structured in the following ways: Introduction, literature review, methodology, results, discussions, conclusion, practical implications, contribution to the study, recommendations, author information, source of funding, conflict of interest, Abbreviation and references.

\section{Literature Review}




\section{Financial Inclusion}

World Bank (2018) define Financial Inclusion (FI) as the process by which all households and businesses regardless of income level have access to and can effectively use the appropriate financial services they need in order to improve their lives. CFI (2018) also defines Financial Inclusion as a state at which individuals access a full suite of financial services at affordable prices, in a convenient manner and with respect and dignity. Such services has to be availed in a responsible and safer manner to consumers and sustainably provided in an appropriately regulated environment (Demirguc-kunt,Klapper, Singer and Oudheusden, 2015). Global and national level policy makers are taking up financial inclusion as an important development agenda and the priority it deserves. For example the $\mathrm{G} 20$ included financial inclusion as a main pillar at the 2009 Pittsburg Summit (Cull, Ehrbeck and Holle, 2014). There are four dimension of financial inclusion namely; access, quality, usage and welfare (Aguera, 2015). At a macro level, financial inclusion can result in to a diversified base of deposits creating a resilient financial system and increased stability (Garcia, 2016). IMF revealed that within a country's level, financial inclusion is affected by the limitations arising from numerous macroeconomic outcomes which includes stability, equality and economic growth (Sahay et al.,2015). Information and communication technology has greatly improved digital financing. The delivery of financial services through digital means of service provision has been increasingly emphasized by governments, development partners and service providers themselves as a good step towards financial inclusiveness (Gabor and brooks, 2017). The provision of services like mobile banking has provided easy ways for electronic transfer payment to the financially excluded people and this method can help reduce theft, financial crimes which are related to cash transaction and reduce the risk of loss. Digital financing appears to be a better solution to those financially and socially excluded (GSMA, 2017). The attempt to support financial inclusiveness will address the challenges of access to finance that may likely hinder the growth of SMEs.

Financial Inclusion Alliance (FIA) (2018) states that the usage of Smartphone's and broadband internet are now important for supporting access to secure and affordable financial services such as money transfers, credit and saving, payments both domestic and international. Alaxandre and Eisenhart (2013) observe that mobile technologies have provided a true imperfection of the finance. The development and the adaptation of digital innovations through partnership for financial inclusion would accelerate the delivery of financial services. Improved financial inclusion propels and plays a vital role in promoting access to credit, use of mobile and automatic teller machine (ATM), savings and easy access to payments (Dorfleitner and Roble,2018). The high increase in financial inclusion can be associated with increased investment level, employment opportunity, higher income level and lower poverty level and that economic growth can only be sustained if a good number of people have access to formal financial services (Umar, 2013). In order to increase financial inclusiveness to majority of the population, financial service providers should lower down the costs of operating accounts, particularly citizens from rural areas (Eton, Mwosi, Ogwel, Edaku and Obote, 2018). There are high transaction costs in lowly populated areas coupled with rigid and complex methods of assessing the risk profile of clients in rural areas and these has been a challenge for the formal financial institutions with a business model to sustainably

offer adequate and effective financial services to rural populations (FAO, 2016a). Addressing the 
challenges like information and communication technology especially how cash transfer, cost of capital, usage and access to finance will definitely play a key role in the growth of SME.

Across-country evidence suggests that at a macro level, the financial institutions have developed a wide range of products and services being offered with a greater outreach and depth, this can reduce inequality amongst the population and increase economic growth and development (Sarma and Pais, 2011). Similarly Martinez, (2011) establishes that financial inclusion helps to increase the pace of inclusive growth and development which has to be sustainable with effective and efficient distribution mechanisms of scarce resources for the wellbeing of the society. CBN, (2012) observe that financial service mobilizes greater household saving, leverage capital for investment and expands the class of entrepreneurs. Such financial services may include Loans, overdraft, Pension, insurance services and modes of payments. Sharma (2016) opine that access to and usage of financial services has proved to be a major driver to economic growth and development. According to (Damodaran, 2013), financial inclusion helps to channel the flow of money in the economy so that both the rich and the poor access it with ease. Financial inclusiveness at household level may support more effectively the macroeconomic policy frameworks. IMF (2018) establishes that financial inclusion at a household level is associated with higher revenue and expenditure of Gross Domestic Product (GDP) and it would equally increase the size of the fiscal multiplier and therefore would indicate that the output elasticity to interest rates will be higher for the countries with greater household financial inclusion. FI therefore covers cost effectiveness and meaningful financial services for those who are under privileged and those who find it a challenge to access financial services and most of them are rural dwellers. Ibor, Offiong and Mendie (2017) argue that much effort should be made by all stakeholders to increase financial access points to more rural areas and develop infrastructural services which promote financial inclusiveness. Government should also develop policies for expansion of financial services to those who are financially excluded in rural areas this will ultimately address the growth of SMEs.

\section{Small Medium Enterprises}

Aga, Francis and Rodriguez-Meza (2015) posit that SMEs are described as nucleus to economic growth and development and are major sources of employment. Studies also note that SMEs are major players in economic growth and development since it provides employment opportunities to citizens and this increases their household income(Palmarudi and Agussalim, 2013; Kamunge, Njeru and Tirimba, 2014). However, (Turyakira \& Mbidde, 2015) posits that inadequate research on SMEs' contribution in networking influences competitiveness a long side limited resources. Rahman(2015) demonstrates that networking among SMEs, in addition to increasing competitiveness allows sharing of employee training costs, cuts costs on consultancy and research \& development, production, export and human resource and financial support. While (Breda \& Fahy, 2011)do not not find causal links between networking of resources combinations, information sharing and international performance, their research supports a positive relationship between a firm's human capital network and international performance. Most SMEs operating in Sub Saharan Africa and in Uganda in particular are faced with many challenges, which affect their operations and long-term survival. It's noted that the business failure rates are alarming with 
very few businesses surviving for a year of their operation. Kazimoto, (2014) opines that governments should support SMEs by ensuring that they play their roles in helping them improve their economies. The stronger the countries' economies the bigger are the opportunity for the citizens of those countries. Kongolo, (2010) posits that globally SMEs operate in similar way, have the same characteristics and face almost the same challenges but differ in their understanding of how they contribute to economic growth and development. Hatch and Cunliffe, (2012) observe that most of the African SMEs are operating in a highly hostile and difficult conditions compared to their counterparts in a more developed economies of the world. Olawale and Garwe (2010) establish that SMEs in Africa finds various obstacles in doing businesses due to unfavorable business conditions arising from unrealistic requirements like higher taxes, higher inflation rates, fluctuation and unstable exchange rates thus making it very difficult for their operation. Ocioo, Akaba and Worwal-Brown (2014) observe that SMEs are faced with the challenge of competition. Globalization has also ushered in technological changes where new products are being developed and this creates stiff competition within the SMEs sector. Egesa, (2010) notes a correlation between technological uptake and a higher business failure rates in Uganda. Notably, the constraints SMEs are faced with could also include weak operational capabilities and limited resources (Sok, Snell, Lee, and Sok, 2017) and particularly in Africa with higher challenges such as technology, innovation, and human capital are a big obstacle to business enterprises (Akeyewale, 2018).

The study conducted by Tinarwo(2016), also established that some of the challenges hampering the growth of SMEs were stiff competitions, lack of markets, unfair treatment exhibited by local authorities and lack of government support, inadequate information and communication technology and training, which has greatly affected most of our SMEs. Dugassa, (2012) establishes that inadequate training and market size has been a major challenge amongst the SMEs in the region. Lack of training makes the SMEs to produce substandard products, which eventually affect the marketing of their products. Therefore, training of the SMEs would help sort out these mess and solve such a challenge. Katua(2014) argues that government should open up institutions specifically to support the training of entrepreneurs that would offer them relevant skills that would improve on the performance of SMEs. Sempala and Mukoki (2018) observe that there is need to train enterprise owners, managers and other operators in order to equip them with the relevant skills and knowledge specially those tailored towards impacting various business management practices. Eton, Okello-Obura, Mwosi, Ogwel, Ejang and Ogia (2019) argue that training institutions should strengthen the information and communication technology training programs by a aligning them to the required job demands as dictated in the field of business.

Gombarume and Mavhundtse (2014) posits that SMEs had the challenge of accessing cheaper loans from the formal financial institutions and this has been a limiting factor in the growth sector. Inadequate access to cheaper credit is recognized world over as a major challenge facing SMEs and these therefore constraints the growth of the existing SMEs. Shah, Nazir, Zaman and Shabir, (2013) opine that it's very difficult to access financial services from formal financial institutions due to their unrealistic demand for collateral; loan guarantees securities and high interest rates. Prohorovs and Beizitere (2015) posit that access to finance and financial services has been some of the major factors constraining the growth and development of SME. Fowowe, (2017) establishes that the inadequacy of capital is believed to be one of 
the major factor affecting SMEs to reach their full potential. Credit availability is very significant for the growth and survival of SMEs Eton, Mwirumubi and Edaku, (2017). They also revealed that policy makers should advocate for financial sector policies that supports financial intermediaries that design relevant products and services for SMEs which are flexible and affordable and thus creating favourable environment that supports creativity and innovation. Government should avail funds to SMEs at low interest rates since SMEs are the driving force in the economy which should be supported (Taiwo,Temitope and Agwu, 2016).

The cost of electricity is abnormally higher in Uganda as compared to other countries in the region which affects the SMEs businesses (Turyahikayo, 2015). The increasing cost of electricity eventually affects the price of the products where the consumer bares the final burden. Reliability of electricity is also a challenge in doing business in Uganda, business owners complain a lot and until now no substantial answer can be given. World Bank (2010) establishes that electricity is still a challenge faced by SMEs in Africa, followed by access to capital. Enterprises in Uganda are still small with limited resources at their disposal and they are left with only option of leveraging on the synergy of resources to complement each other. Fujita and Thisse, (2013) observe that accessibility of resources and their availability to SMEs can help them maximize the benefit and market share as a result of economies of scale as well as internationalization. Sorasalmi and Tuovinen (2016) argue that SMEs are confronted with diverse challenges which include technological knowhow and hostile business environment that affects their survival as compared to developed economies. Kamukama, (2013) observes that technological advancement is growing at a faster rate and therefore SMEs should recognize and appreciate technology to compete favorably in the market. The success of any SMEs would depend on the ability to innovate in order to meet consumers taste and preferences and this will increase market coverage, which means a firm may have competitive advantage over others (Idris, 2016). The level of competition is increasing on daily basis therefore, SMEs need to be creative and innovative and focus on improvement of their products and services, quality, quantity, and this would motivate employees Farrokhian and Soleimani, (2015). SMEs with effective technological capabilities can easily adapt to the changing market environment whose consumer tastes and preference are rapidly changing Ajonbadi, (2015). According to Murrithi, (2017) the study establishes that inadequate information is an obstacle facing SMEs in Africa and this challenges affects Uganda as well. The information related would include marketing, laws regulating to their operations and any other information, which can be of help to their businesses. Eton, Mwosi, Mutesigensi and Ebong, (2017) argue that information is critical since financial institutions would want information related to personal characteristics and credit worthiness of information on guarantors which are very essential in giving out loans. Based on the above, researchers have established that SMEs have failed to achieve their long-term targets in the economy. For example, (Ali, Rashid, \& Khan, 2014) establish a negative impact of small-scale industries on poverty output in Pakistan. They recommended simplification of lending procedures, enforcement of credit rights and reduction in credit costs. Beck, Demirguc, \& Levine (2003) demonstrate that SMEs are not robust in reducing poverty. The authors could not establish a causal link between SMEs growth and poverty. The growth impact is rather spread across both large and small firms. Similarly, (Straka, Birciakova, \& Stavkova, 2015) show that the argument for 
SMEs contribution to household income is a relative one in Pakistan. Households' opinion that SMEs contribute to standards of living depends on the environment in which households live and work. SMEs in Uganda, Northern Uganda more specifically Lango sub region need the required support to meet the growth of SMEs.

\section{Financial Inclusion and Small Medium Enterprises}

Financial Inclusion (FI) refers to a change in one's mindset as an economic agent on how to see money and profit and aims to eliminate any barrier in accessing and utilization of financial services and this is supported by the existing infrastructure. It's noted that more than half of the world economic challenged adults do not have bank accounts and this therefore leave them vulnerable to exploitation, theft and this results in to heavy losses World Bank, (2012).Promoting Fl in a global perspective would widen economic inclusion and this will improve on the financial condition of the population and thus uplift the standard of living of those disadvantaged SMEs who are financially excluded Khan, (2011). Financial inclusiveness would encourage the sustainability of SMEs through enhancing their access to cheaper sources of finance which would be vital in supporting their growth Batance et al., (2018). The intermediation between savings and investments with efficient financial inclusion are most likely to improve the efficiency of SMEs and facilitate a better financial system Aduda and Kalunda, (2012). While we have noted that under utilizing capital is one of the causes of growth constraints amongst the SMEs, they are very important in the investment strategy and expansion of small and macro enterprises amongst the rural therefore increasing financial inclusiveness of the citizens Aldaba, (2011).SMEs are financially constrained and the relaxation of credit constraints or accessibility to finance amongst the SMEs compared to larger firms will most likely lead to employment and the gains in the labour productivity, therefore contributing to economic growth and development Ayyagari et al., (2016). Its observed that the establishment and growth of SMEs will lead to employment and labour productivity across the country which leads to access to formal finance. World Bank (2018) also notes that the gains found from implementation of policy reforms geared towards boosting the growth of SME by establishing credit bureaus across the country will improve financial inclusiveness of the citizens. Beck and Cull, (2014) observe that financial inclusiveness is significant for the growth of SMEs in sub-Saharan Africa.

There are various factors that affect the level of a country's financial inclusiveness and financial development, including the quality of the formal financial institutions, availability of relevant information, income per capita, governance and the regulatory framework Park and Mercado,(2015). Most SMEs in Sub-Saharan Africa do not even attempt to apply for a bank loan due to challenges of complicated collateral requirements, high interest rates, and complicated documentations. UNIDO, (2015) opines that the cost associated with capital transaction is always too high which greatly affect the performance of SMEs. World Bank (2016) establishes that high concentration, weak competition and the prevalence of public ownership in the financial intuitions are specifically some of the key constraints in financing SMEs. Financial inclusiveness supports the principle of financial stability which provides a strong risk management and financial facilities. It would also close the financial inclusion gap within the SMEs and these can bring a significant gain in the growth. However a very low financial inclusion in the region 
suggests important untapped potential for the growth of increased access to finance by SMEs. Popov and Rocholl, (2016) posit that increased constraints to financing during recession may put more pressure on employment by SMEs than by large firms. Kazimoto, (2014) observed that governments and other stake holders should therefore avail financial facilities and access to finance at a reasonable interest rate and use up to date information and communication technology in business and marketing and these can be through improved network and training. Legas, (2015) establishes that SMEs in Africa face a lot of challenges and among them includes financial inclusion, non-favorable laws, regulations, and poor infrastructure, which affects the growth of SMEs. The government should take the responsibility of providing SMEs with a conducive environment for their growth and development, seeking for international and local opportunities for its SMEs, develops fair and encouraging policies and making it easy for SMEs to access financial facilities at a fair and affordable rate Fariza, (2012). Access to credit is given based on business age, and the level of education of the owner Wang, (2016). Moreover, existing literature does not offer substantial information on financial inclusion and growth of Small and Medium Enterprises in Uganda thus making the current study timely.

\section{Methodology}

The research design was cross-sectional survey. This is a study design in which the researcher interacts with respondents in a single count. The design is useful in describing a phenomenon as it stands at the time of investigation (Kumar, 2011). The design was appropriate to study the relationship between financial inclusion and growth of SMEs in Lango sub-region as it stood at the time of investigation. The study was conducted in Lango sub-region comprising of SMEs in manufacturing, services, production, and merchandize operating in Lira, Apac, and Dokolo districts. The study based on a sample size of 320 (Krejcie\& Morgan, 1970), drown from a target population of 1900 business units (UBOS, 2018). The area under survey was divided into districts, manufacturing, services, production, and merchandize businesses in the SMEs sector were purposively selected. However, simple random sampling was used to select individual SMEs owners into the study. The study used a structured questionnaire, which comprised close-ended questions to understand the extent of financial inclusion and growth of SMEs. The questionnaire had four sections: The first section constituted 5 items that sought to understand participants' background information. These items were designed according to nominal and ordinal scales of measurement. The second section constituted 13 items that sought to understand the contributions of SMEs. These items were designed according to an interval scale of measurement. The third section constituted 20 items that sought to understand the challenges faced by SMEs in Lango subregion. These items were designed according to an interval scale of measurement. The fourth section had 13 items that sought to understand financial inclusion in Lango sub-region. The items were designed according to an interval scale of measurement. All the interval items were based on a five-point likert scale, ranging from 1 (strongly disagree) to 5 (strongly agree). Financial inclusion was operationalized in terms of accessibility, degree of usage, adaptability to, and cost of financial products. The items were developed basing on statements gleaned from respective sub-sections of literature review. The instrument was tested for reliability using Cronbach's alpha coefficient, as shown in the table below 


\section{Table 1: Reliability}

\section{Variable List}

Cronbach's Alpha Cronbach's Alpha Based on Standardized Items $\mathbf{N}$ of Items

\begin{tabular}{lccc}
\hline SMEs contribution & .710 & .760 & 13 \\
SMEs challenges & .879 & .885 & 20 \\
Financial inclusion & .883 & .899 & 13 \\
\hline Overall & $\mathbf{0 . 8 2 4}$ & $\mathbf{0 . 8 4 8}$ & $\mathbf{4 6}$ \\
\hline \hline
\end{tabular}

\section{Source: Field data, 2020}

The table shows an overall reliability coefficient of 0.824 . This implies that the items used in this instrument are internally stable and and consistent. Therefore, the instrument can be used for conclusion and generalizability of results.

The study used factor analysis to reduce the items to a few that could explain the variables uniquely. For example, the items on the: contribution of SMEs were reduced to 8 items, the challenges of SMEs were reduced to 13 items, while financial inclusion were reduced to 10 items.After isolating out the items with high factor loadings, the study adopted descriptive statistical measures (mean and standard deviation) to portray the level SMEs, their challenges and financial inclusion. The study used correlation analysis to determine the strength of the relationship between the study variables. Regression analysis was conducted to provide a linear prediction in the growth of SMEs as a result in changes in financial inclusion.

\section{Results}

Overall participation indicates that $62.9 \%$ were male while $37.1 \%$ were female. This implies that the study was dominated by male more than female. The dominance of men than women derives from the fact that men have higher access to financial services than women do. Men have the required collateral security compared to women, who struggle to identify potential guarantors. Most of the participants (57.7\%) belonged $30-39$ years age bracket, followed by $33.3 \%$ who belonged to $18-34$ years age bracket. Little participation was observed among those with 50 years above. The statistics imply that the adults, followed by the youths dominated the study. This variation in participation of ages at which Ugandans accumulate financial wealth to engage in business. Most of the youths do not have adequate financial capital to start business. Participation according to education level indicates that majority had secondary education (45.0\%) followed by those whose education was above secondary $(37.1 \%)$ while $17.9 \%$ had primary education. The dominance of participants with secondary education derives from the effects if Lord's Resistance Army war that crippled the education of many. However, participants whose education was above secondary suggests the trend of turning away from white-collar jobs' expectations to blue-collar. In terms of experience, $46.7 \%$ had over 10 years' experience in business, followed by those with $5-9$ years' business experience (36.1\%). The statistics suggests that the study participants had noticeable experience in business. Marching this experience and their level of education suggests some stability in growth and expansion of SMEs in the region. The study also indicates that most of the 
participants operate merchandize (36.8\%), followed by those who provide services $(29.2 \%)$, followed by manufacturers $(18.2 \%)$ and least of all production (15.8\%). The variation in participation based on the nature of business derives from the fact that merchandize and services businesses require lower capital to establish and operate than manufacturing and production.

\section{Factor analysis}

The researchers raised many claims in the instrument, some of which were highly correlated. To eliminate redundancy, factor analysis was adopted to remove the highly correlated while leaving out those that were unique yet accounting a greater portion of the original variable list.

\section{Table 2: Factor analysis on SMEs}

\begin{tabular}{|c|c|c|c|}
\hline \multirow[b]{2}{*}{ Variable List } & \multicolumn{3}{|c|}{ Component } \\
\hline & 1 & 2 & 3 \\
\hline
\end{tabular}

L. I enjoy interacting with my customers

2. Allow proper money flow

3. It teaches me to be entrepreneurial

0.747

4. It increases my household income

0.606

5. t has made me become popular

0.786

6. I have accumulated some property, like land

0.717

7. It has helped me stay in close contact with potential customers 0.707

8. It has taught me to build networks with important people

0.706

\begin{tabular}{lcccc}
\hline Total & 4.67 & 1.74 & 1.12 \\
\% of Variance & 35.94 & 13.42 & 8.59 \\
Cumulative \% & 35.94 & 49.36 & 57.96 \\
\hline \hline
\end{tabular}

\section{Source: Field data, 2020}

The system extracted three factors accounting for about $58 \%$ of the originally. The extracted variables were used in further analysis. High factor loadings were evident in: becoming popular $(r=.786)$, accumulating some property like land $(r=.717)$, maintaining a close contact with customers $(r=.707)$ and networking $(r=.706)$.

Table 3: Factor analysis on challenges of SMEs 
1. Unrealistic demand for collateral securities

2. Competition from foreign firms

3. Stiff competition from domestic firms

4. Small market size

5. Unfair treatment from local authorities

0.716

0.683

0.669

0.698

6. Unrealistic demand for loan guarantees

0.676

7. Inadequate access to cheaper credit

8. High inflation rates

9. Inadequate training in ICT.

10. Expensive loans

0.612

0.502

11. High taxes

0.557

12. Unreliable electricity

13. Ever changing technology

\begin{tabular}{lcccccc}
\hline Total & & \multicolumn{4}{c}{0.446} \\
\% of Variance & 6.49 & 2.05 & 1.39 & 1.32 & 1.22 & 1.01 \\
Cumulative \% & 32.43 & 10.26 & 6.97 & 6.61 & 6.09 & 5.04 \\
\hline \hline
\end{tabular}

\section{Source: Field data, 2020}

The extracted variables account for about $67.4 \%$ of the original variables. High factor loadings were evident in: unrealistic demands for collateral securities $(r=.716)$, competition from foreign firms $(r=.683)$, stiff competition from domestic firms $(r=.669)$, small market size $(r=.698)$, and unfair treatment from market authorities $(r=.676)$.

\section{Table 4: Factor analysis on financial inclusion}


. I find it easy using the available financial services

2. My financial service providers serve me with respect and dignity 0.564

3. I find it easy to make deposits with my financial providers 0.812

4. I have easy access to an automatic teller machine (ATM) 0.805

5. I find it easy to make payments to my service providers 0.768

6. I find it cheap to operate a bank account 0.764

7. I find it switching from one bank to the other

0.755

8. I find it cheap to operate a mobile money account

0.733

9 My financial service providers are supervised by a superior bank

0.727

10. I find it easy to transfer money via my mobile phone

0.708

\begin{tabular}{lccc}
\hline Total & 6.30 & 1.52 & 1.08 \\
\% of Variance & 48.43 & 11.70 & 8.28 \\
Cumulative \% & 48.43 & 60.13 & 68.41 \\
\hline \hline
\end{tabular}

\section{Source: Field data, 2020}

Three factors components were extracted, accounting for $68.4 \%$ of the original variables. In the first component, the largest factor loading was evident in: making it easy to make deposits with financial providers $(r=.812)$ while the least factor loading was evident $(r=.708)$.

\section{Objective one: contributions of SMEs}

To understand the contributions of SMEs, this paper adopted descriptive measures of mean and standard deviation. Mean scores above 3.5 indicated challenges that affect SMEs the most, mean scores below 3.5 indicated challenges that affect SMEs the least while mean scores from 2.5 to 3.4 indicated challenges that affect SMEs moderately.

\section{Table 5: contribution of SMEs}




\begin{tabular}{llcc}
\hline \hline \multicolumn{2}{l}{ Variable List } & Mean & Std. Deviation \\
\hline 1. & It has taught me to build networks with important people & 4.29 & .847 \\
2. $\quad$ It has helped me stay in close contact with potential customers & 4.20 & .884 \\
3. $\quad$ I enjoy interacting with my customers & 4.18 & .767 \\
$4 . \quad$ Allow proper money flow & 3.94 & .857 \\
5. $\quad$ It has made me become popular & 3.90 & .992 \\
$6 . \quad$ I have accumulated some property, like land & 3.75 & .981 \\
$7 . \quad$ It teaches me to be entrepreneurial & 2.35 & .951 \\
$8 . \quad$ It increases my increase my household income & 1.73 & .835 \\
\hline Average & 3.54 & $\mathbf{0 . 8 8 9}$ \\
\hline \hline
\end{tabular}

\section{Source: Field data, 2020}

Participants identified building networks (mean = 4.29; Std. =.847), remaining in close contact with potential customers (mean = 4.20; Std. =.884) and interacting with customers (mean =4.18; Std. =767) as key among the contributions of SMEs to business operators. The statistics indicate most of the enterprises investigated are customer-oriented. The possibility of maintaining a close contact with customers might arise from the fact SMEs does not have many resources to devote to advertising, which might attract many customers. On the lower end, participants identified 'increase in household income' (mean $=1.73$; Std. $=.835)$ as a contribution to SMEs business operators. The statistics imply that increasing household income is no longer a motivator to SMEs. It is more of a short-term goal than a long-term goal in business and particularly, SMEs. Generally, the statistics suggest that participating in SME business offers important gains. Actually, a close examination of the standard deviation does not show significant deviations in participants' opinions. Nearly all the participants seem to support the claims raised in the study.

\section{Objective two: Challenges faced by Small and Medium Enterprises}

To understand the challenges faced by SMEs, this paper adopted descriptive measures of mean and standard deviation. Mean scores above 3.5 indicated challenges that affect SMEs the most, mean scores below 3.5 indicated challenges that affect SMEs the least while mean scores from 2.5 to 3.4 indicated challenges that affect SMEs moderately.

\section{Table 6: Challenges of SMEs}




\begin{tabular}{|c|c|c|c|}
\hline \multicolumn{2}{|c|}{ Variable List } & \multirow{2}{*}{$\frac{\text { Mean }}{4.41}$} & \multirow{2}{*}{$\frac{\text { Std. Deviation }}{.835}$} \\
\hline 1. & Competition from foreign firms & & \\
\hline 2. & Stiff competition from domestic firms & 4.29 & .761 \\
\hline 3. & Small market size & 4.13 & .977 \\
\hline 4. & Unreliable electricity & 4.05 & .927 \\
\hline 5. & Unfair treatment from local authorities & 3.99 & .958 \\
\hline 6. & High taxes & 3.97 & .909 \\
\hline 7. & Inadequate training in information and communication technology (ICT) & 3.90 & .777 \\
\hline 8. & Unrealistic demand for collateral securities & 3.88 & .875 \\
\hline 9. & Inadequate access to cheaper credit & 3.87 & .772 \\
\hline 10. & Ever changing technology & 3.86 & .973 \\
\hline 11. & Unrealistic demand for loan guarantees & 3.76 & 1.059 \\
\hline 12. & High inflation rates & 3.66 & 1.091 \\
\hline 13. & Expensive loans & 3.35 & 1.015 \\
\hline \multicolumn{2}{|c|}{ Average } & 3.93 & 0.918 \\
\hline
\end{tabular}

\section{Source: Field data, 2020}

Participants indicated stiff competition from foreign firms as the problem that mostly challenges the operation of SMEs in Lango (Mean = 4.41; Std. = .835). Most of the good and services produced and sold in the sub-region provide same consumer tastes, designs and preferences that as imported goods. In the wood manufacturing firms for example, they assemble wall-units, office counters, beds, chairs, tables and doors out of imported softwood. Such products made in Uganda cannot beat the utility a consumer is likely to maximize if one bought a similar imported good. Our markets are flooded with imported commodities offered at very low prices while providing expected consumer tastes. Participants indicated competition from domestic firms (mean $=4.29$; Std. $=.761$ ) is the second challenge to SMEs' operation in the region. Nearly, the goods, and services produced and sold by SMEs are more of a duplication of imported commodities. We have some manufacturing firms in Lira, producing oil cooking oil and toilet paper. The numbers of companies in Uganda that produce goods are many. Participants also pointed to small market size (mean $=4.13$; Std. $=.977)$. Least affecting challenges pointed to expensive loans (mean = 3.35; Std. =1.015), high inflation rates (mean =3.66; Std. =1.091) and unrealistic demand for loan guarantees (mean =3.76; Std. =1.059). Participants regarded expensive loans as affecting SMEs the least. However, going for loans is optional. Secondly, apart from those who operate on loaned money, the need for guarantors is an optional problem. Thirdly, high inflation rate increases the costs of borrowing. This is also optional and affects a limited set of SMEs. Whereas the mean scores indicate 'competition from foreign firms' as key among the challenges of SMEs businesses, standard deviation suggests 'stiff competition from foreign firms'. 
To understand how financial inclusion supports the growth of SMEs, it was important to understand the state of financial inclusion in Lango sub-region. This paper adopted descriptive measures of mean and standard deviation to examine the state of financial inclusion in Lango sub-region. Mean scores above 3.5 indicated challenges that affect SMEs the most, mean scores below 3.5 indicated challenges that affect SMEs the least while mean scores from 2.5 to 3.4 indicated challenges that affect SMEs moderately.

\section{Table 7: Financial inclusion}

\begin{tabular}{llcc}
\hline \hline Variable List & Mean & Std. Deviation \\
\hline 1. & I find it easy to make payments to my service providers & 4.23 & .839 \\
2. $\quad$ I have easy access to an automatic teller machine (ATM) & 4.21 & .865 \\
3. $\quad$ I find it switching from one bank to the other & 4.21 & .909 \\
4. $\quad$ I find it easy to make deposits with my financial providers & 4.19 & .796 \\
5. $\quad$ I find it cheap to operate a mobile money account & 4.11 & .955 \\
6. $\quad$ My financial service providers are supervised by a superior bank & 4.08 & .848 \\
7. $\quad$ I find it cheap to operate a bank account & 4.06 & .926 \\
8. $\quad$ I find it easy to transfer money via my mobile phone & 4.01 & .906 \\
9. $\quad$ My financial service providers serve me with respect and dignity & 3.94 & .896 \\
10. I find it easy using the available financial services & 2.53 & 1.342 \\
\hline Average & $\mathbf{3 . 9 6}$ & $\mathbf{0 . 9 2 8}$ \\
\hline \hline
\end{tabular}

\section{Source: Field data, 2020}

The statistics indicate that most of the participants find it easy to make payments to their financial service providers (mean $=4.23$; $\mathrm{Std} .=.839$ ), they have easy access to Automatic Teller Machines (mean $=$ 4.21 ; Std. =.865), and find it easy switching from one bank to another (mean =4.21; Std. =.909). These statistics imply that financial inclusion has simplified their business operations. However, participants seem not to find it easy using available financial services (mean $=2.53$; Std. $=1.342$ ). The statistics imply that some of the financial services are technical and not user-friendly, or they are user friendly but users lack acquaintance to using them. Generally, the results indicate a high level of financial inclusion in Lango sub-region (mean =3.96). This seems to suggest that most of the SMEs have benefited from governments' efforts to promote financial inclusion. The results indicate that participants find financial inclusion relevant in their business operations. A scrutiny of standard deviations does not show significant deviations in participants' opinions on the issues raised in the study relating to the contributions of financial inclusion.

To understand how financial inclusion supports the growth of SMEs in the region, the paper adopted linear regression. Linear regression is a mathematical function that shows the relationship between the independent variable (financial inclusion) and the dependent variable (SMEs).

\section{Table 8: Model Summary}




\begin{tabular}{ccccc}
\hline \hline Model & $\mathbf{R}$ & R Square & Adjusted R Square & Std. Error of the Estimate \\
\hline & & & & \\
1 & $.362(\mathrm{a})$ & .131 & .128 & .45109 \\
\hline \hline
\end{tabular}

a Predictors: (Constant), Financial Inclusion

The model summary shows that the relationship between financial inclusion and SMEs growth $(r=.362)$ is weak. The statistics suggest that a change in financial inclusion is associated to a weak change in growth and operations of SMEs. Extension of financial services such as formal banking, mobile money, automatic teller machines, agent banking, etc. bear a weak change in SMEs growth and consequently their operations. The (R Sqaure $=.131)$ indicates that financial inclusion in Lango sub-region accounts for as low as $13.1 \%$ of the growth and operations of SMEs. Even when the variables are standardized, (Adjusted R square =.128), the change in SMEs accountable to financial inclusion remains as low as $12.8 \%$. These statistics suggest that financial inclusion accounts for a small portion of growth and operations of SMEs in the region. There must be another set of factors that provide interplay in growth and operations of SMEs in the region.

\section{Table 9: ANOVA(b)}

\begin{tabular}{llccccc}
\hline \hline Model & & Sum of Squares & Df & Mean Square & F & Sig. \\
\hline 1 & Regression & 8.843 & 1 & 8.843 & 43.457 & $.000(\mathrm{a})$ \\
& Residual & 58.808 & 289 & .203 & & \\
& Total & 67.651 & 290 & & & \\
\hline \hline
\end{tabular}

a Predictors: (Constant), Financial Inclusion

b Dependent Variable: Contribution

The Analysis of Variation (ANOVA) shows whether the independent variable accounts for the changes in the dependent variable. Using the regression sum of squares, the statistics indicate a smaller regression sum of squares (8.843) than the residual sum of squares (58.808). The statistics suggest that financial inclusion is not adequate in explaining the changes in the growth and operations of SMEs in the region. However, $(p$-value $=.000)$ indicates that there exists a linear relationship between financial inclusion and growth of SMEs in the region.

\section{Table 10: Coefficients (a)}

\begin{tabular}{llccccc}
\hline \hline Model & \multicolumn{2}{c}{ Unstandardized Coefficients } & Standardized Coefficients & & $\mathbf{t}$ & Sig. \\
\cline { 2 - 5 } & & $\mathbf{B}$ & Std. Error & Beta & B & Std. Error \\
\hline 1 & (Constant) & 2.408 & .174 & & 13.854 & .000 \\
& Financial Inclusion & .286 & .043 & .362 & 6.592 & .000 \\
\hline \hline
\end{tabular}

\section{a Dependent Variable: Contribution}

The beta coefficient $(B=.286)$ indicates that a change in financial inclusion by a single unit is likely to vary SMEs growth and operations by approximately $28.6 \%$. When the variables are standardized, a change in financial inclusion is likely to vary SMEs growth and operations by $36.2 \%$, evidence from (Beta 
$=.362$ ). The statistics agree with ANOVA results of the low contribution of financial inclusion in the growth and operations of SMEs in Lango sub-region.

\section{Table 11: Summary of findings}

Objectives Major Findings

sntribution of SMEs

1. Promotes networking with important people

2. Promotes close customer contact

3. Promotes high level interaction with potential customers.

2. Challenges of SMEs

1. Stiff competition from both domestic and foreign firms

3. Relationship between financial inclusion and SMEs growth

1. Significant and weak

4. Predictive role of financial inclusion on SMEs growth

1. Very low, accounting for only $12.8 \%$ of the level of SMEs growth

\section{Source: Field data 2020}

\section{Discussion}

The study examined the contributions of Small Medium Enterprises in Lango sub-region. Evidence shows that SMEs promote networking between business owners and important people. The important people might range from owners of production materials to owners of financial products. This study offers support to (Breda \& Fahy, 2011) who found that networking in business improves business performance in terms of human capital, information and access to resources. Networking helps business firms to identify areas complementary resources and level of information exchange. Networking encourages sharing of cost of training and cost of consultants, research and development, export, production, human resources and financial capital; which improve a firm's competitive advantage (Rahman, 2015; Turyakira \& Mbidde, 2015). Firms in Lango sub-region that demonstrate networking include Gracious Palace Company limited, Ngetta Tropical holdings among others. While the findings indicate the importance of networking, there is dearth of research on networking especially among SMEs in northern Uganda. Our research further demonstrates a close link of networking to maintaining close contacts with customers. Unlike large firms, SMEs have to keep a close contact with their customers least they lose them to their competitors. This agrees with (Ludmila \& Stanislava, 2015) who emphasize the necessity of SMEs to know their business relationships with suppliers and customers. Relationships with customers build competitive advantage and enlarge the market size, especially with manufacturing businesses. The findings further support (Fourie, 2015) who establishes that a close contact with customers helps firms to identify and satisfy customer needs, which saves the firm from the costs of acquiring new customers. 
Participants showed that SMEs contribute little to their household income. Increasing household income is a short-term goal that no longer motivates business owners. In Uganda, living standards among business owners are highly daunting. The fact that most SMEs collapse before their first birthday affirms the finding. The findings agree with (Straka, Birciakova, \& Stavkova, 2015) who found that SMEs owners perceive differently its importance in standard of living. They would not see any difference based on income level or job possibility. Not to underestimate government's effort in promoting SMEs in Uganda, their impact on household income is rather relative. The findings of the current study support (Beck, Demirguc, \& Levine, 2003)who argue that much as the association between SMEs development and economic growth appears positive(Ali, Rashid, \& Khan, 2014), cross-country comparisons do not indicate significant relations between SMEs and measures of depth and breadth of poverty.

The study sought to determine the challenges affecting Small Medium Enterprises. The findings show that SMEs suffer stiff competition from foreign firms; they also suffer competition from domestic markets, and have a small market size. Most of the SMEs engage in production of goods that are similar to imported goods such as cooking oil, timber products, detergents to mention but a few. They have no option than to strive for a market share, which turns small in the end. The findings agree with (Ocioo, Akaba and Worwal-Brown, 2014; Tinarwo, 2016; World Bank, 2016) who support the view that SMEs suffer from stiff competition and are weak competitors in both domestic and foreign markets, a factor that is more driven by their lack of innovative ideas. However, the findings slightly disagree with (Dalberg, 2011; Fjose, grunfeld, \& Green, 2010)who demonstrated that SMEs in developing countries lack financial capital for growth and expansion. The disagreement was slightly correct because SMEs still suffer financial challenges, but the case of Lango demonstrates severe challenges from competition, both foreign and domestic example is imported cooking Oil vs locally manufactured oil.

The study examined how financial inclusiveness supports the growth of Small medium enterprises in region. Financial inclusion eases payments to service providers, access to ATM services, and switching from one bank to another. These services make transaction very easy. The findings agree with (Gabor \& Brooks, 2017; Dorfleitner \& Roble, 2018; Eton, Mwosi, Edaku, Ogwel \& Obote, 2018). The presence of multiple providers of financial services increases the flow of money in the economy and reaching it to the 'unbanked' population (Damodaran, 2013). The findings justify government's action to promoting financial inclusion across all social and economic sector in the country. However, participants indicate some difficulty in using some of these financial services. The fact that some of the SME owners are not highly educated, they find it difficult to interact with some of these financial services. The study found that financial inclusion plays a significant role in SMEs growth. However, the role-played appears low, which suggests an influence other factors in the relationship. The findings supports (Ayyagari et al., 2016) who assert that SMEs are constrained financially and find it hard to access credit compared to large firms. Though they might have access to credit, they often fall short of such requirements like guarantors, collateral security and business profile, which agrees with (Eton, Mwosi, Mutesigensi, Ebong, 2017).Most of the SMEs lack such information that financial providers need to assess their credit worthiness. While such process requirements save financial providers from loses and properly manage credit provision, SMEs view them as bureaucratic with tough regulations (Park and Mercado, 2015).We 
therefore, argue that much as financial services appear to be available to SMEs, the cost associated to acquiring and servicing them affect their financial performance (UNIDO, 2015). In addition, the platforms on which some of the financial services are provided are too technical for SME owners to operate. The findings however, disagree with (GSMA, 2017) who asserts that financial service providers allow for easy transfer of payments from SMEs to suppliers and service providers, reduce theft, financial crimes and the risk of loss. Unlike SMEs in urban areas, SMEs in rural areas are highly vulnerable to financial risks and theft. Financial inclusion is likely to increase the level of investment, employment opportunity and poverty reduction, which are the core functions of SMEs in the economy. Finally, the study established a weak relationship between financial inclusion and SMEs growth; however, the relationship was statistically significant.

\section{Conclusion And Practical Implications}

The study sought to establish the relationship between financial inclusion and SMEs growth in Lango sub-region. SMEs are important to economic growth at macro level since they provide employment and improve household income. At micro level, SME owners are able to build networks with important people, which helps them source quality human capital, access cheap sources of raw materials and capital. Additionally, networks help SME owners to maintain contact with suppliers and customers. This paper

presents a new look at SMEs as contributors to the economy: they promote networking in addition to their traditional contribution to employment and household income. Despite the contributions of SMEs, this paper demonstrates that SMEs struggle to out compete their rivals at both local and international markets, which narrows down their market size. This conclusion differs from previous studies that present expensive loans as the greatest obstacle to SMEs operations. This paper has not generalized the outcome on expensive loans as least among the challenges to SMEs growth because of its lack of categorization of financial products and financial providers, which is likely to present contradicting results. The major outcome of the study is that financial inclusion is significant in supporting SMEs growth however, is generally weak. The weakness stems from the cost of acquiring and servicing financial services, the difficulty in using some of the financial services, and the way financial providers treat financial users, which demonstrate some lack respect and dignity.

\section{Contribution to the study}

This study contributes to the existing literature on financial inclusion and SMEs growth but explicitly contributes unique evidence from northern Uganda. This study offers an original and evidence-based support for promoting ATM and shared banking platforms that allow clients to switch through banks. The study provides testable relationships between financial inclusion and SMEs growth that extend research on financial inclusion in developing economies. The study provides networking as one of the important contributions of SMEs as it links them to owners and suppliers of production resources and customers. While networking is a concept that is common to corporate organizations, this study reveals its importance in small and medium enterprises. Business managers and entrepreneurs will recognize the importance of networking in growing businesses. This study has shown the roles of finance providers, 
how financial inclusion would be improved and may redirect SMEs in adopting better strategies in the growth and development of SME sector in the region. The study may help managers adopt best practices in their managerial decisions.

\section{Recommendation}

The study took a cross-sectional survey to collect data on financial inclusion and SMEs growth in northern Uganda. There is need for a longitudinal study on financial inclusion with a focus on financial providers and their impact on SMEs growth. Financial providers should continue sensitizing the public on the available financial services beyond credit services, which are common and known. Since the world is turning digital, financial service providers should encourage their clientele to use digitalized financial services, which are cheap, secure and risk averse. Bank of Uganda, which is the supervisor of financial intermediaries, should monitor these institutions on costs of loans. SMEs should be innovative while they produce goods that stand the competition at both domestic and foreign markets. This study has shown how SMEs contribute to networking in business, yet studies that relate networking and growth of SMEs are still scanty. Future researchers should consider investigating the relationship between SMEs and networking in growth of SMEs.

\section{Abbreviations}

CBN-Cenbank., CFI-Center for Financial Inclusion, FAO- Food and Agricultural organization

GDP- Gross Domestic Product, IMF- International Monetary Fund, NDP11- National Development Plan Two, OECD- Organizations of Economic Corporations and Development, UBOS- Uganda Bureau of standard, UIA- Uganda Investment Authority, UNIDO- United Nations Industrial Development Organizations.

\section{Declarations}

\section{Availability of data and materials}

Not applicable

\section{Competing interest}

There is no conflict of interest in this study.

\section{Source of Funding}

This study was not funded by any organization or person other than the authors

\section{Author's contributions}


All authors contributed adequately in this study from the start to the end. They all read the final document and approved it.

\section{Acknowledgement}

Not applicable

\section{Author Information}

Dr. Marus Eton (Ph.D) is a Senior lecturer in the department of business studies in the Faculty of Economics and Management sciences at Kabale University, Kabale Uganda. Fabian Mwosi is Ph.D Candidate at Nkumba University, Uganda and a lecturer at Bishop Barham University College Kabale, Uganda. Constant Okello Obura is a professor at Makerere University and Dean Faculty Eastern African School of Library and information Science. Dr. Abanis Turyehebwa (Ph.D) is a senior lecturer at the faculty of Economics and Management Sciences in the department of business studies Kabale University, Kabale Uganda, Gilbert Uwonda is a senior lecturer in the department of economics and statistics in the faculty of business and development studies, Gulu University, Gulu Uganda.

\section{References}

Abanis, T.,\& Arthur, S. (2013). Financial management practices and business performance of small and medium enterprises in western Uganda. African Journal of Business Management, Vol. 7(38), pp. 3875-3885.

Adcorp, (2014). International expansion integrated annual report. www.adcorpgroup.com

Aduda, J., \&Kalunda, E. (2012). Financial Inclusion and Financial Sector Stability with Reference to Kenya; A Review of literature. Journal of Applied Finance and Banking, 2(6),

Aga, G. A., Francis, D.,\& Rodriguez-Meza, J. (2015). SMEs, age and Jobs: A review of the literature, Metrics and evidence. World Bank policy research working paper (7493)

Aguera, P. (2015). Financial Inclusion, Growth and Poverty reduction. ECAAS Regional Conference. Brazzavile, March 23, 2015

Ajonbadi, H.A. (2015). "Technological Drive to Small and Medium Enterprises(SMEs) growth in Nigeria" in $5^{\text {th }}$ conference of Directors of Entrepreneurship Development Centers. Ilorin, pp.1-15

Akeyewale, R. (2018). Who are the winners and losers in Africa's Continental Free Trade area? World Economic Forum. www.weforum.org/agenda/2018/10

Aldaba, R.M. (2011). SMEs access to finance in selected East Asian Economies, ERIA research project report 2010-14, (pp.291-350. Jakarta: ERIA 
Alaxandre, C., \&Eisenhart. L. C. (2013). Mobile money as an engine of financial inclusion and lynchpin of financial integrity. Washington journal of law, technology and arts, 8(3), 285-302

Ali, S., Rashid, H., \& Khan, M. A. (2014). The role of small and medium enterprises and poverty in Pakistan: An empirical analysis. Theoretical and Applied Economics, 21 (2014)(4(593)), 67-80.

Ayyagari, M.A., Demirguc-Kunt., \&Maksimovic. (2016). "Access to finance and Job Growth: Firm level evidence across developing countries", World Bank Policy Research Working Paper No. 7604 Beck, T., Demirguc, A., \& Levine, R. (2003). Small and medium enterprises, growth and poverty: Crossscountry Evidence. World Bank Policy Research working Paper.

Beck,T., \& Cull, R. (2014). SME Finance in Africa. Journal of African Economies 23(5): 583ff

Bowen, M., Morara, M., \&Muraithi, S. (2009). "Management of business challenges among small and micro enterprises in Nairobi -Kenya" KCA journal of business management, vol.2, no.1, pp.16-31

Breda, K., \& Fahy, J. (2011). Network resources and international performance of high Tech SMEs. Journal of Small Business and Enterprise Development, 18(3), 529-555.

CBN. (2012). Measuring Nigerian's Financial Inclusion Strategy. WWW.Cenbank.com

Center for Financial Inclusion - CFI. (2018). CFI's Vision of Financial Inclusion. Derived from:http://www.centerforfinancialinclusion.org/our-definition-of-financial-inclusion

Chan, S. H., \& Lin, J. J. (2013). Financing of micro and small enterprises in China: An exploratory study. Journal of Strategic Change, 22(7-8), 431-446.

Cull, R., Ehrbeck,T., \& Holle, N. (2014). Financial Inclusion and Development: Recent Impact Evidence. Focus note 92, Washington. D.C. CGAP

Dalberg. (2011). Report on support to SMEs in developing countries through financial intermediaries. Dalberg.

Damodaran, A. (2013). Financial inclusion: Issues and challenges. AKGEC International Journal of Technology, 4(2), 54-59.

Demirguc-Kunt, A., Klapper, L., Singer, D.,\&Oudheusden, P. V. (2015). The Global Findex Database 2014: Measuring Financial Inclusion around the World. World Bank Group Policy Research Working Paper 7255

Dorfleitner, G.,\& Roble. (2018). The Financial Performance of the Health care industry: A Global regional and Industry Specific Empirical Investigation. European Journal of Health Economics, 19(4): 585-594. 
Dugassa, T. G. (2012). The context of entrepreneurship education in Ethiopian Universities. Management Research Review 35(3/4) 225-244

Egesa, K. A. (2010). Indigenous firms Survival in Uganda: Is there a role for increased technology use? Bank of Uganda working paper

Eton. M., Mwirumubi. R.,\&Edaku, C. (2017). Challenges faced by development partners in supporting the growth and development of commercial enterprises in Lira district, Northern Uganda. Journal of Education and Practice. Vol.8, No. 11, pp. 88-94 www.iiste.org

Eton. M., Mwosi. F., Ebong. C.D., \& Ogwel. B. P. (2018). Government Interventions in Supporting SME growth in Lira district, Northern Uganda. International Journal of Emerging research and development. www.ijernd.comVol, issue 2, pp. 107-113

Eton. M., Mwosi. F., Mutesigensi, D.,\& Ebong. C. D. (2017). Credit financing and performance of SMEs in Lira Municipality, Uganda. Research journal of finance and accounting. Vol. 8, No. 8, pp. 121-127 www.iiste.org

Eton. M., Mwosi.F., Ogwel, B.P., Edaku. C., \& Obote, D. (2018). Financial Inclusion and Women Empowerment in Uganda. A Case of Lango Sub Region, Northern Uganda. Economics, Commerce and Trade Management: An International Journal (ECTIJ) Volume 2, No.1

Eton. M., Okello-Obura, C., Mwosi,F., Ogwel, B.P., \& Ongia, F. (2019). Information and Communication technology Adoption and the Growth of Small Medium Enterprises in Uganda. Empirical Evidence from Kampala City Council Authority. International Journal of Academic Research in Business and Social Science, 9(12), 877-893.

Fariza, H. (2012). Challenges for the Internationalization of SMEs and the Role of Government: The Case of Malaysia. Journal of International Business and Economy, (2012) 13(1), pp, $\quad 97-122$

Farrokhian, R., \& Soleimani, F. (2015). "Assessing Capabilities for innovation -the case of Iranian Kalleh meat Product Company" in international conference on operation excellence and service engineering, pp.23-32

Fatoki, O. O.,\& Smit, A.V.A. (2011). Constraints to Credit access by new SMEs in South Africa: A SupplySide analysis. African Journal of Business Management (AJBM), Vol.5No. 4, pp.1413-1425

Fjose, S., Grunfeld, L. A., \& Green, C. (2010). SME and growth in Sub-Saharan Africa: Identifying the role and obstacles to SME growth. MENON Business Economics.

Fourie, L. (2015). Customer satisfaction: a key to survival for SMEs? Problems and Perpsectives in Management, 13(1-3), 181-188. 
Fowowe, B. (2017). Access to finance and firm performance; evidence from African Countries. Review of development finance, 7(1), 6-17.

Fujita, M., \& Thisse J. F. (2013). Economics of agglomerations: Cities, industrial locations from institutional theory, Research Policy, 43(4),772-791

Gabor, D., \& Brooks, S. (2017). The digital Revolution in financial inclusion: international development in the Fintech era. New Political Economy,22,(4), 423-436

Garcia, M. (2016). "Can Financial Inclusion and Financial Stability Go Hand in Hand?" Economic Issues, 21(2): 81-103

Garikai, B.W. (2011). Exportation challenges by small and medium enterprises and possible exportation strategies. Retrieved from http://www.articlebase.com/business- $\quad$ 4056101.html

Gombarume, F.B.,\& Mavhundutse.S. (2014). Challenges faced by small to medium scale enterprises: A case study of Chitungwiza, Zimbabwe. Greener Journal of Business and Management Studies 4(4):103107

GSMA. (2017). Mobile money global event, Tanzania, 2017, Retrieved from.https://gsma.com/mobilefordevelopment/events/mobile-money-global-even

Hatch, M. J., \& Cunliffe, A. L. (2012). Organization Theory: Modern, symbolic and Postmodern perspectives. Oxford University Press

Ibor, B., Offiong. A.I., \& Mendie.E.S. (2017). Financial inclusion and performance of micro small and medium scale enterprise. International Journal of research- granthaalayah. Vol. 5, Issue 3, pp. 104-122

IMF. (2017). Uganda seventh review under the policy support instrument- Press release and staff report January 2017 IMF Country report no. 17/7

IMF. (2018). Financial Inclusion in Asia Pacific," IMF Departmental Paper 18/17, Washington, DC Kamukama, N. (2013). Intellectual capital; company's invisible source of competitive $\quad$ advantage; Competitiveness Review; An international Business Journal, 23(3),pp.260- 283

Kamunge, M.S., Njeru, A., \&Tirimba, O.I. (2014). Factors affecting the performance of Small and Macro enterprises in Limuru town market of Kiambu County. International Journal of Scientific and Research Publications, 4(12), 1-20

Katua, N. T. (2014). The role of SMEs in employment creation and Economic Growth in Selected Countries. International Journal of Education and Research. Vol. 2 No. 12

Kazimoto, P. (2014). Assessment of Challenges Facing Small and Medium Enterprises towards International Marketing Standards: A Case Study of Arusha Region Tanzania. International Journal of 
Academic Research in Accounting, Finance and Management Sciences Vol. 4, No.2, pp. 303-311

Khan, S.R. (2011). Fighting poverty with Microcredit: Experience of the Grameen Bank and Other programmes in Bangladesh. Washington DC: World Bank

Kongolo, M. (2010). Job creation versus shedding and the role of SMEs in economic development African Journal of Business Management Vol. 4(11) pp 2288-2295

Krejcie R.V.,\& Morgan. D. W. (1970). Determining Sample Size for research activities. Educational and Psychological measurement 1970, 30, 607-610

Kristiningsih ,\& Trimarjono, A. (2014). Analysis of factors affecting the development of small and medium enterprises. A Case study of SMEs in Surabaya, The $7^{\text {th }}$ NCFB and Doctoral Colloquim; $2014 \mathrm{pp}$. $141-154$

Kumar, A. (2011). Research and Writing Skills. New York, NY: Lulu Press. (9781-4466-0560-8)

Lega, H. (2015). Challenges to entrepreneurial success in Sub-Saharan Africa: A Comparative perspective European Journal of Business and Management Vol. 17. 11

Love, I.,\& Martinez Peria. M. (2015). How Bank Competition Affects Firms' Access to Finance. World Bank Economic Review 29(3)

Love, I., \& Peria, M.M.S. (2012). How Bank Competition affects firm's access to finance. World Bank Policy Research Working Paper, No 6163

Ludmila, S., \& Stanislava, G. (2015). The application of business network approach for small and medium enterprises (SME) with regard to their buying behavior. Journal of Competitiveness, $7(2), 62-74$.

Martinez, M. V. (2011). The Political Economy of Increasing Financial Access. Georgetown: Georgetown University Press

Nwanko,O.,\& Nwanko, N.O. (2014). Sustainability of financial inclusion to rural dwellers in Nigeria: Problems and way forward. Research journal of finance and accounting, 5(5); 24-31

Ocioo, C.E., Akaba. S.,\&Worwal-Brown, D. (2014). Globalization and Competitiveness: $\quad$ Challenges of Small and Medium enterprises (SMEs) in Accra, Ghana. International Journal of Business and Social Science 5(4): 287-296

OECD. (2010) SMEs, Entrepreneurship and Innovation, OECD Publishing, Paris

OECD. (2016). Job creation and Local economic development, OECD Publishing, Paris

Olawale, F.,\& Garwe, D. (2010). Obstacles to the growth of new SMEs in South Africa: A Principal component analysis approach. www.academicjournals.org/ajbm 
Olowe, F. T., Moradeyo, O.A.\&Babalola, A.T. (2013). Empirical Study of the Impact of

Microfinance Banks on SMEs Growth in Nigeria. International Journal of Academic Research in Economic and management Sciences, 2(6); 116-127

Palmarudi. M., \& Agussalim. M. (2013). Human Capital and Survival of Small Scale Food Processing Firms under Economic Crisis in central Java Indonesia. Australian Journal of Business and Management Research 3(1);16-29

Park,C,-Y., \& Mercado. R.V. (2015). Financial Inclusion, Poverty, Income Inequality in Developing Asia "Asian Development Bank Economics Working Paper 426.

Popov, A.,\&Rocholl. J. (2016). “Do credit shocks affect labour demand? Evidence for employment and wages during the financial crisis" Journal of Financial Intermediation 36(October):16-27

Prohorovs, A.,\&Beizitere, I. (2015). Trends, Sources and amounts of financing for micro-enterprises in Latvia. Procedia-social and behavioral sciences, 213(66), 404-410

Rahman, M. M. (2015). SMEs and Networking: A Resource-based view perspective. Entrepreneurship, Micro-Multinationals, and International New Ventures.

Reeg, C (2013). Micro, small and medium enterprise upgrading in India-Learning from success cases. KFW-Development Research. German Development Institute. pp.1-229

Sahay, R., Cihak, M., N’Diaye, P., Barajas, A.,Mitra, S., Kyobe, A., NianMooi, Y., \&Reza S. $\quad$ Yousefi (2015). Financial Inclusion: Can it Meet Multiple Macroeconomic Goals? IMF Staff Discussion Note 15/17, September

Sarma, M., \& Pais, J. (2011). Financial Inclusion and development. Journal of International Development, 23(5),613-628

Sempala. R., \& Mukoki. J. (2018). Determinants of Growth of Micro, Small and Medium Enterprises (MSMEs) in Developing Countries Evidence from Rubaga Division, Kampala District Uganda. SSRN Electronic Journal. January 2018

Shah, S.F.H., Nazir. T., Zaman. K.,\& Shabir, M. (2013). Factors affecting the growth of enterprises: A Survey of the literature from the perspective of small and medium sized enterprises. Journal of enterprises transformation, 3:53-75

Shama, M. K. (2016). Financial Inclusion: A Prelude to economic status of vulnerable group. International Journal of research-Granthaalayah, 4(12), 147-154

Sok.P., Snell.,Lee., \& Sok. (2017). Linking entrepreneurial orientation and small service firm performance through marketing resources and marketing capability: A moderated mediation model. Journal of service theory and practice, 27(1), pp.-231-249 
Sorasalmi, T., \& Tuovinen, J. (2016). Entering emerging markets, A dynamic framework dynamics in logistics (pp. 675-683) Berlin: Springer

Straka, J., Birciakova, N., \& Stavkova, J. (2015). Impact of SMEs on living standards of Czech Rural households. Economics and Sociology, 8(4), 51-64.

Taiwo, J. N., Temitope, F.O.,\& Agwu. M.E. (2016). SMEs financing and its effects on Nigerian Economic Growth: European Journal of Business, Economics and Accountancy

Terzi, N. (2015). Financial Inclusion and Turkey. Academic Journal of Interdisciplinary Studies, 4(1), 269276

Tinarwo, R. (2016). An Investigation into the challenges faced by Small to Medium Enterprises in Zimbabwe: A Case of Gaza land Market Journal of Business and management Vol. 18, 9(2) pp. 148-153

Turyahikayo, E. (2015). Challenges faced by Small and Medium enterprises in raising finance in Uganda. International Journal of Public Administration and Management Research 3(2);21-33

Turyakira, P., \& Mbidde, C. I. (2015). Networking for SMEs in Uganda: A conceptual paper. African Journal of Business Maanagement, 9(2), 43-49.

UBOS. (2018) Uganda National Household survey 2016/2017. Kampala, Uganda: UBOS, Available at http://sun-connect-ea.org/wp- content/uploads/2018/12/2017_UNHS_260922017-

Final_Presentation.pdf

UIA. (2016). Annual Investment Abstract, FY 2015/2016 Available at www.eBiz.go.ug

Umar, A. (2013). Cross-Country variation in household access to financial services. Journal of banking and Finance 32 (1), 2493-2500

UNIDO. (2015). Country programmes for inclusive and sustainable industrial development. United Nations Industrial Development Organizations

World Bank. (2010) World Bank Enterprise Survey, 2010. Washington DC: World Bank

World Bank. (2012) financial system and development: World development report. New York: Oxford University Press

World Bank. (2014). Finance for all? Policies and Pitfalls in expanding access. World Bank Policy Research Report. Washington, DC: World Bank

World Bank. (2016) "Competition in the GCCSME lending Markets: An Initial Assessment". Middle East and North Africa Region GCC Country Unit report, Washington, DC 
World Bank. (2018), "Doing Business 2018, Reforming to create Job," A World Bank Group Flagship Report 